\title{
Urban Biodiversity: Perception, Preference, General Awareness, and Threats in Two Cities (Niamey and Maradi) of Niger
}

\author{
Salamatou Abdourahamane Illiassou, ${ }^{1}$ Abdoulaye Amadou Oumani, ${ }^{2}$ Laouali Abdou, ${ }^{1}$ \\ Ali Mahamane, ${ }^{1}$ and Mahamane Saadou ${ }^{2}$ \\ ${ }^{1}$ Faculty of Agronomic Science, University of Diffa, BP 78, Diffa, Niger \\ ${ }^{2}$ Faculty of Agronomy and Environmental Science, Dan Dicko Dankoulodo University of Maradi, BP 456, Maradi, Niger \\ Correspondence should be addressed to Salamatou Abdourahamane Illiassou; assalamat2@yahoo.com
}

Received 21 August 2016; Revised 26 October 2016; Accepted 21 November 2016

Academic Editor: Eric Koomen

Copyright (C) 2016 Salamatou Abdourahamane Illiassou et al. This is an open access article distributed under the Creative Commons Attribution License, which permits unrestricted use, distribution, and reproduction in any medium, provided the original work is properly cited.

\begin{abstract}
This study was undertaken to obtain direct and useful data that support biodiversity awareness and management in two cities of Niger. 800 questionnaires were administrated to the populations of Niamey and Maradi. The results show that $99 \%$ of respondents are aware of the importance of biodiversity in urban areas. They assign multiple roles to it; however, climatic and managerial reasons explain why plants are most preferred to animals in these cities. Furthermore, shade and fruits are the criteria for plant species selection, and that explains the abundance of Azadirachta indica A. Juss. and Mangifera indica L. Even though plants are preferred to animals in houses, $47 \%$ of the respondents practice animal husbandry. Most of the animals are left wandering with risks of destruction of green areas, road unsafety, and zoonotic contamination. The results of this study also showed the ignorance of $55 \%$ of the respondents about the presence of wildlife in urban areas. The proliferation of cockroaches and rats could be an indication of insanitary conditions that are faced in some areas of the cities as mentioned by $81 \%$ of the respondents. This study shows the importance of local knowledge in the identification process of urban problems.
\end{abstract}

\section{Introduction}

Urban landscapes, tagged as incompatible with nature for a long time [1], are nowadays recognized for their variety of species. Indeed, whether native or exotic, ruderal, spontaneous, or domestic, biodiversity could be found in the city. It lies on street edges, in the wasteland/dumpsites, under rocks, in houses, the roofs of houses, gardens, green areas, and wetlands, and many other places. Several studies have highlighted the existence of significant biodiversity in the city [2-6]. According to Purro and Kozlowski [7], cities could even be considered as hotspot for biodiversity. In fact, in a city like Fribourg, for example, 721 species of plants of which $1 / 4$ belong to the Red List are encountered on only $10 \mathrm{~km}^{2}$. In the city of Bujumbura, Bigirimana et al. [8] have identified 567 plants species in urban gardens. Luniak [9] also found that among, the wildlife, birds and mammals are becoming more frequent in urban areas.
Biodiversity plays an important role in the urban environment and in the well-being of the population. From the environmental point of view, plants improve the local climate by cooling the air through evapotranspiration and hence contribute to the reduction of energy consumption [10]. They serve also as a sink for pollutants. Indeed, plants have a great capacity of air pollutants absorption and dispersion [11] and help reduce pollution in urban areas. Plants and animals such as birds and insects are often used as bioindicators of environmental disorders [12]. Aside from their contribution to environmental resilience, urban biodiversity has sociocultural and medical importance. These values lie in the role of animals as pets and as good companions to humans. Local populations attribute high considerations to animals, which they also used as taboos. Plants through green spaces contribute to social unity. People go there for exchanges and leisure such as football games and other physical exercises. These green spaces also contribute to mental 
ailment remediation and have psychological advantages [1315]. Indeed, better health conditions could be achieved based on more appropriate and sustainable conditions related to natural exposure than when focusing on only health interventions such as drug consumption [16]. Ulrich [17] even observed an improvement in the postsurgery recovering rate of patients exposed to a natural landscape view. The results of his study showed a shorter postoperative hospital stay of patients, a reduction in painkillers intake, and a reduction in postsurgical complications when patients stay in room with tree view as compared to patients in room with wall views. Some plants and animals are used in part or entirely for medicinal and nutritional purposes. They contribute to aesthetic and spiritual well-being of the population.

Despite the values and importance attributed to the urban biodiversity, its survival in such environment remains problematic in the face of a burgeoning population [18]. In fact, cities accommodate more than $50 \%$ of the world human population. They are growing in numbers and in size worldwide [19]. This urbanizing process represents a biodiversity disturbance factor that contributes to the homogenization of biodiversity, the introduction of exotic species, and the fragmentation of ecosystems [20].

In the developing world, the competition for space between human and biodiversity on one hand and the waste generated by anthropogenic activities on the other hand represent a pressure on ecosystems and a threat to local biodiversity. This is the case in Niger, one of the poorest countries in the world. In fact, the rapid urbanization in this country is characterized by a growth in population number followed by a densification in built-up areas and a sprawl especially in cities like Niamey [21]. The urban population in this country has a relatively high growth rate $(2.9 \%$ in Niamey and $4.3 \%$ in Maradi) [22] with a corollary increase in land demand in order to accommodate the population. However, poverty hinders the Niger government's capacity to provide basic amenities such as water, electricity, roads, and gutters making the well-being of the population difficult. Moreover, the municipalities have limited financial and technical capacities for an adequate and integrated urban waste management. Another important factor that affects the success of urban environmental and biodiversity management is the lack of city-dwellers' implication in such program.

While population has been an asset in urban management in other countries, in Niger, the public opinion or perceptions are often overlooked in the urban planning process. To achieve sustainable management of cities and the conservation of urban biodiversity, there is a need for population implications since urban areas are largely dominated by human beings [23]. Only few studies have focused on the urban biodiversity in Niger [24, 25] and on the perception of city-dwellers about biodiversity [26] and none have focused on the impact of urbanization on urban biodiversity. It is in this context that the present study was conducted on populations' perceptions and preferences about urban biodiversity. This study represents the baseline for a diagnosis on urban biodiversity in Niger. Its main objective was to obtain direct and useful data to support biodiversity awareness and management in order to contribute to urban environmental policy and decision making in Niger and to improve the human well-being. It aims specifically at (1) identifying the values attributed to urban biodiversity by the population, (2) understanding the preferences of the population about domestic biodiversity, (3) evaluating the awareness of the population with regard to urban wildlife, its presence, and factors attracting it, and (4) identifying the threats to biodiversity in these cities.

\section{Methodology}

2.1. Study Sites. This study was carried out in two cosmopolitan and fast urbanizing cities of Niger: the City of Niamey and that of Maradi distanced by $660 \mathrm{~km}$. Niamey, the political, administrative, and economic capital of Niger, is located in the western part of the country between $3^{\circ} 20^{\prime} 00^{\prime \prime}$ and $13^{\circ} 35^{\prime} 00^{\prime \prime}$ North latitude and $2^{\circ} 00^{\prime} 00^{\prime \prime}$ and $2^{\circ} 15^{\prime} 00^{\prime \prime}$ East longitude (Figure 1). Maradi represents the third city of Niger and is located in southcentral Niger between $13^{\circ} 25^{\prime} 30^{\prime \prime}$ and $13^{\circ} 33^{\prime} 00^{\prime \prime}$ North latitude and $7^{\circ} 04^{\prime} 30^{\prime \prime}$ and $7^{\circ} 10^{\prime} 30^{\prime \prime}$ East (Figure 1). These cities were initially villages. During colonization, they became administrative centres that have grown into cities today. Niamey became the capital of Niger in 1926 and the first urban centre of Niger in 1952 while the city of Maradi was created after a serious flood that caused the relocation of the population in 1948. These two cities have also undergone several administrative reforms. Indeed, they were erected in urban community under Law number 98-32 of 14 September 1998 and in city under Law number 2002-016 of 11 June 2002 [27]. In order to facilitate their management, Niamey and Maradi were further divided into communes: five communes for Niamey and three communes for Maradi.

These cities are also characterized by a fast growing population. In fact, the population of Niamey city underwent $463.1 \%$ increase in 35 years and that of Maradi city registered a $745.73 \%$ increase [22]. The demography of Niamey varied from 218,366 inhabitants in 1975 to 1,011,277 inhabitants in 2012, while that of Maradi rose from 35,882 inhabitants in 1972 to 267,606 inhabitants in 2012 [22]. Djerma/Sonrai and Haousa are the most represented ethnic groups in Niamey while Haousa group dominate in Maradi. Agriculture, residential livestock, and trade represent the principal activities in these cities $[28,29]$.

The climate of the two cities is semiarid of a SaheloSudanese type characterized by two contrasted seasons: a short rainy season of three (3) to four (4) months and a dry season of nine (9) to eight (8) months. The mean values of rainfall, temperature, and humidity recorded in Maradi are lower than those of Niamey [30]. The city of Niamey registered an annual mean rainfall value of $518 \mathrm{~mm}$ and a mean temperature value of $29.84^{\circ} \mathrm{C}$ calculated over 34 years (19812014). The average annual relative humidity is $49.15 \%$. Indeed, the annual mean values of $476.9 \mathrm{~mm}$ and $28.11^{\circ} \mathrm{C}$ have been recorded, respectively, for rainfall over 34 years (1981-2014) and $48.94 \%$ is the annual mean humidity value calculated on 24 years (1990-2014) for the city of Maradi.

The landscape of the Niamey city is diverse and composed of plateaus, sandy terraces, and valley. Its vegetation could be categorized into domestic plantations, gardens around 

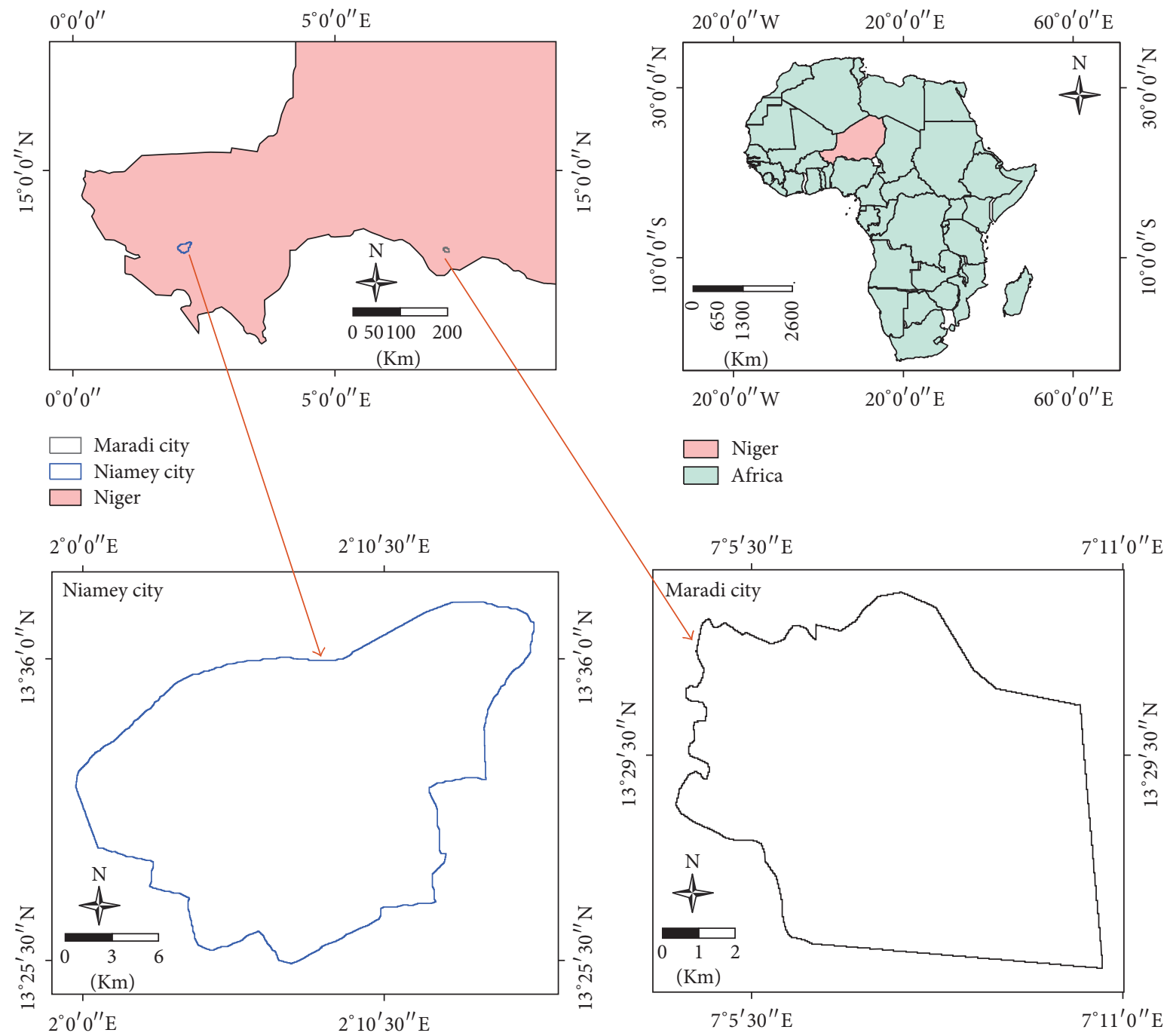

Figure 1: Geographical localization of the cities of Niamey and Maradi.

ponds, and valleys of the river Niger and the Gounti-Yéna, roadside trees, relics of green belts, and few public green spaces [21]. Combretaceae on plateaus and shrub-steppe on the sandy terraces characterize the natural vegetation. Apart from domestic plantations, the vegetation cover of the Maradi city is composed of tree plantations, the green belts, and gardens of a wide variety of fruit trees that are located along the Maradi Goulbi-valley. The grass cover is present and diversified.

2.2. Data Collection. An ethnobiological survey was conducted in 2013 in the two cities of Niamey and Maradi to determine the public perceptions, preferences, and general awareness in urban biodiversity in Niger. It consisted in the administration of 800 questionnaires to citizens of the two cities based on a stratified sampling as follows: 100 questionnaires per commune. As Niamey is composed of five (5) communes and Maradi is composed of three (3) communes, we had 500 respondents from Niamey city and 300 from Maradi city. The respondents were selected based on nine activity groups as follows: group of students (20 respondents), group of teachers (10 respondents), group of traders (5 respondents), group of fishermen, farmers, gardeners, and hunters (15 respondents), group of health and sanitation workers (10 respondents), group of environmentalists (10 respondents), group of industries (5), group of urbanists (5 respondents), group of jobless people (15 respondents), and group of people working in other categories (5 respondents). This grouping was realized in order to take into consideration the viewpoints of actors with different background and factors that impact directly or indirectly on urban biodiversity and its management.

Once selected, the respondents were given the questionnaire to fill; but when illiterate, we asked them the questions and filled the questionnaire for them. The questionnaires were designed using two question formats: the closed-ended questions that guide the respondents in their responses based on predetermined responses to be selected and the openended questions, which give no restrictions for answers. The latter are used when there is no enough knowledge 

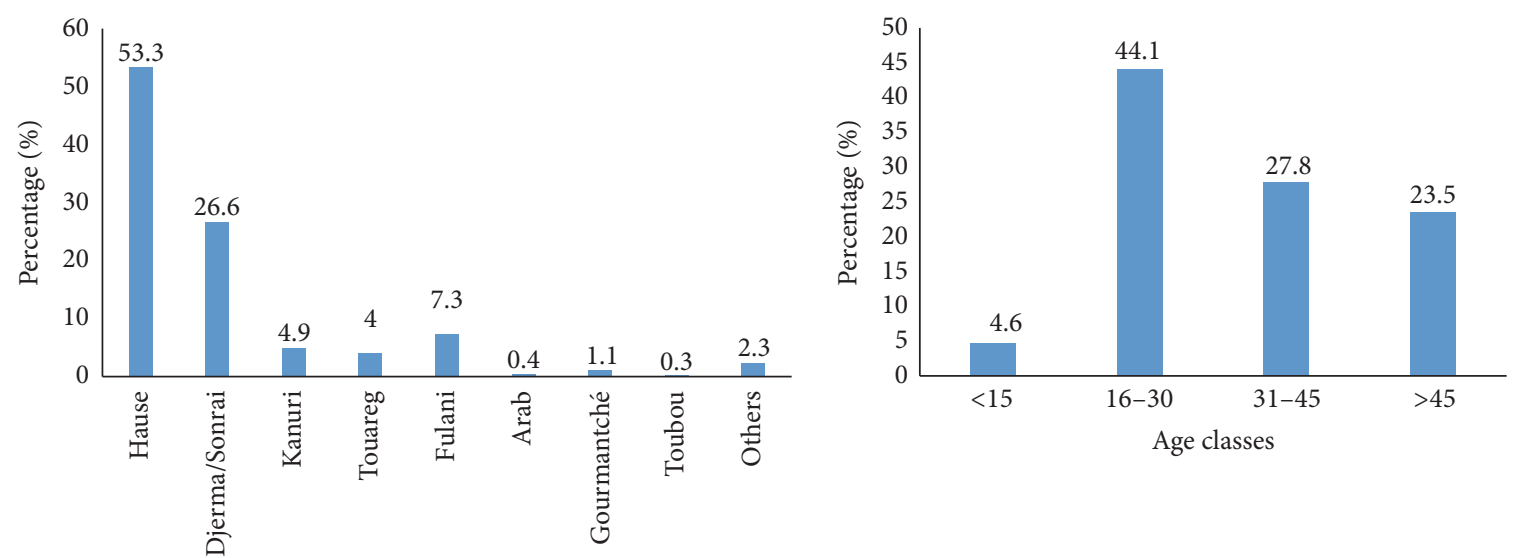

Ethnic groups
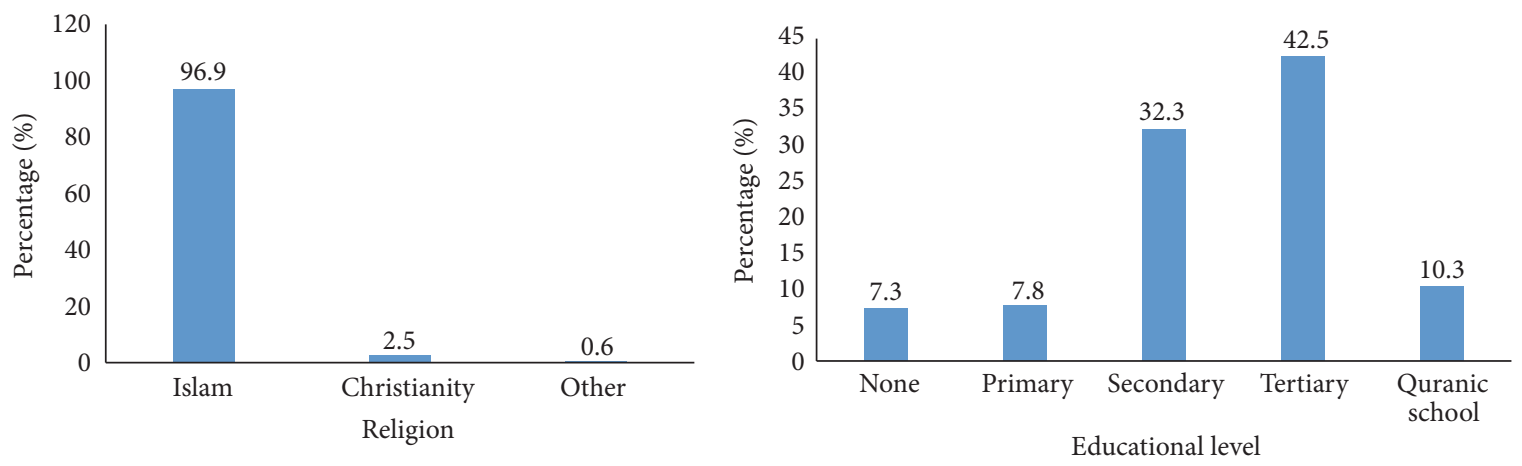

FIGURE 2: Social characteristics of the sample population.

or understanding of a phenomenon under study or when a richer understanding of a subject is needed [31]. The questionnaires were composed of 30 questions and divided into five sections. The first and fifth sections are composed of only closed questions while the remaining sections are composed of closed questions followed by open-ended ones (see Appendix).

Section one describes the general characteristics of the participants and it includes closed questions about gender, age, religion, ethnicity, level of instruction, activities, city, and communes. Section two gives an overview of the perceived values regarding biodiversity in urban areas of Niger. Section three is about the presence and preferences in domesticated biodiversity and reasons that determine their selection. Section four is assessing the general awareness of the participants with regard to the presence of wildlife in houses or cities and factors that attract them. Furthermore, it is important to note that this section is also composed of other questions that have not been included in this study. They are about perceptions on zoos, importance of museum, wild animals' rearing in cities, awareness of laws protecting plants and animals, etc. Section five summarizes the threats to biodiversity as observed by the population in the city.

2.3. Processing and Analysis of Data. For the purpose of this paper, two steps were used in the data analysis process: a pretreatment of the open-ended questions and the analysis of the data. Indeed, a conventional content analysis was applied to open-ended questions. It is a flexible method for analyzing text data [32], especially when there is no enough literature on a given subject that will facilitate the determination of categories to be analyzed. Hence, responses were read thoroughly in order to identify key words that will help determine the different codes/categories to be analyzed. Once the codes/categories are identified and the answers classified accordingly, then the data was analyzed. Closedended questions were directly processed with SPSS software.

Once the data was processed, a descriptive analysis was applied. Response frequency histograms with respect to a given issue and percentages histograms of the total number of respondents were done in Excel. The following formula for obtaining the frequency responses was used for this purpose $[33,34]$ :

$$
\operatorname{Fr}=\frac{n_{r}}{N} \times 100
$$

$n_{r}$ is the number of respondents who mentioned the response $r$, and $N$ is the total number of respondents.

\section{Result}

3.1. Social Characterization of the Sample Population. In total, 800 people were surveyed in this study, of which $406(50.8 \%)$ were women and $394(49.3 \%)$ were men. These respondents' characteristics concerning age, ethnicity, religion, and education are given in Figure 2. Indeed, all of the Niger 

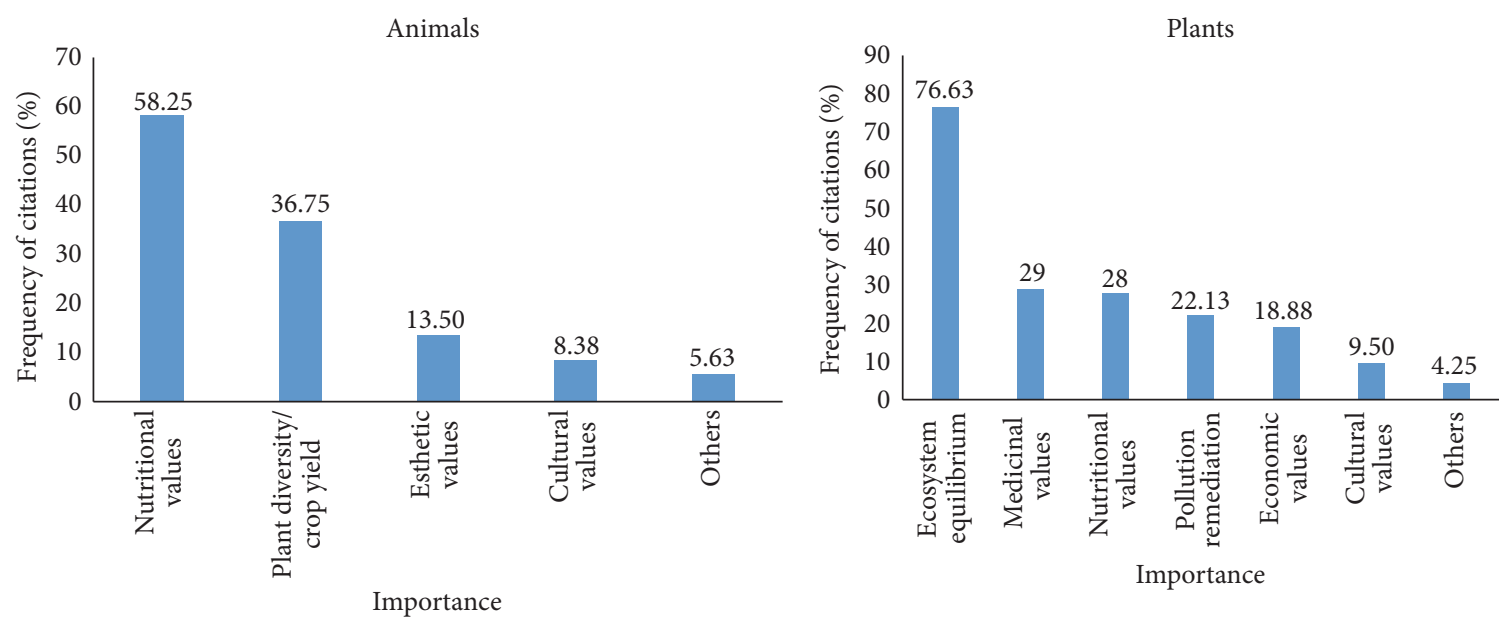

FIGURE 3: Importance of urban biodiversity cited by the population.

ethnic groups were sampled; however, Hausa (53.3\%) and Zarma/Sonrai (26.6\%) were the most represented ethnic groups. $44 \%$ of respondents were between 16 and 30 years old and about $96.9 \%$ of the respondents are Muslims. The level of education is characterized as follows: $7.3 \%$ of respondents are illiterate (no formal school or Quranic one) and 10.3\% have only attended Quranic schools against $82.4 \%$ who attended formal schools (Figure 2).

3.2. Perceptions about Values of Urban Biodiversity in Niger. This survey has highlighted the importance of biodiversity in these urban areas as perceived by $99 \%$ of the respondents. Hence, the three most important values attributed to animals are their nutritional values (58.25\%), their contribution to the improvement of plant diversity and crop yield (36.75\%), and their aesthetic value (13.50\%) (Figure 3). As for plants, their primary role cited is their contribution to ecosystem equilibrium $(76.63 \%)$, followed by their medicinal importance (29\%) and then their nutritional values (28\%).

\subsection{Domestic Biodiversity in Houses: Presence and Preferences}

3.3.1. Presence of Domestic Biodiversity. The results of this study show that plants are preferred to animals in the cities, and only $37 \%$ of the respondents have both in their houses (Figure 4).

3.3.2. Preferences in Domestic Animals and Reasons. The citation's frequency shows that ovine, poultry, and caprine are the most domesticated animals in cities of Niamey and Maradi (Figure 5). The ovine and caprine representing the small ruminants are much appreciated for their nutritional, economical, and cultural values, whereas poultry is most selected because it is easy to handle, it has nutritional values, and citizens have passion for them (Table 1).

Other birds, mammals, and reptiles are also being domesticated by the respondents (Figure 5). The most cited reason for the selection of animals in houses is related to the management. Other important reasons are the use of cats

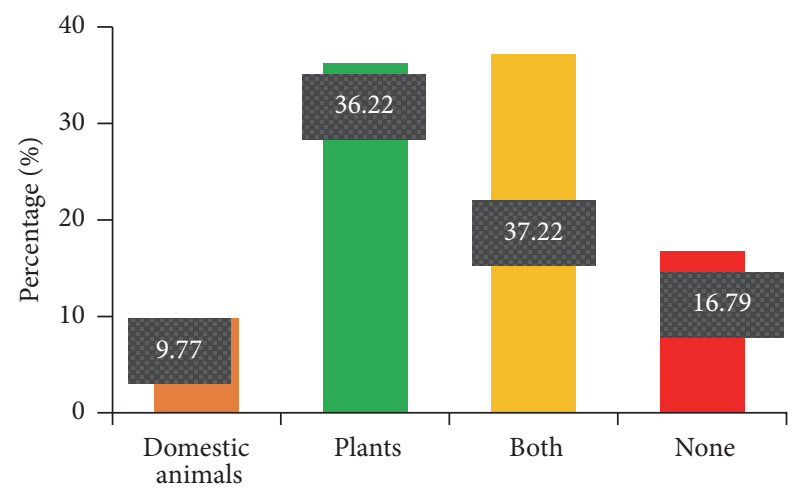

FIgURE 4: Presence of biodiversity in houses.

against pests such as rat and the use of donkeys, camels, and cows for transportation (Table 1).

3.3.3. Preferences in Plants and Reasons. The survey also revealed the most common plant species. There are the neem (Azadirachta indica), mango trees (Mangifera indica), ornamental plants/flowers (e.g., Clerodendrum, Bougainvillea), and Terminalia and citrus in the concessions or the front of the houses (Figure 6). The reasons given for these choices by the respondents are the shady cover and nutritional and aesthetic values (Figure 6).

3.4. Urban Wildlife in the Cities. More than half of the respondents $(47.4 \%$ and $7.6 \%)$ are not aware of wildlife presence in urban areas (Figure 7).

Among the wildlife, birds and mammals recorded the highest number of citations and amphibians the least. Errant animals are also present in these urban areas even though they are not wildlife. The most abundant species that were cited by the respondents are dove, cockroach, rat, and lizard (Figure 8).

According to the respondents, in urban areas, mammals, reptiles, and errant animals are mostly attracted to feed 
TABLE 1: Reasons for choices of domestic animals in percentage (\%).

\begin{tabular}{|c|c|c|c|c|c|c|c|c|c|c|}
\hline \multirow{2}{*}{ Reasons } & \multicolumn{10}{|c|}{ Animals } \\
\hline & Small ruminant & Cow & Poultry & Duck & Pigeon & Dog & Cat & Donkey & Horse & Camel \\
\hline Company & 0 & 0 & 0 & 11.76 & 32.14 & 23.81 & 34.61 & 0 & 0 & 0 \\
\hline Cultural & 31.25 & 8.34 & 5.36 & 0 & 0 & 0 & 0 & 0 & 0 & 0 \\
\hline Nutritional & 49.63 & 20.83 & 28.57 & 23.53 & 25 & 0 & 0 & 0 & 0 & 0 \\
\hline Economical & 49.39 & 41.67 & 8.93 & 0 & 3.57 & 0 & 0 & 0 & 40 & 0 \\
\hline Passion & 12.69 & 8.33 & 14.29 & 29.41 & 17.86 & 0 & 0 & 0 & 20 & 0 \\
\hline Pest control & 0 & 0 & 0 & 0 & 0 & 0 & 23.08 & 0 & 0 & 0 \\
\hline High reproductive capacity & 6.82 & 0 & 0 & 0 & 0 & 0 & 0 & 0 & 0 & 0 \\
\hline Easy management & 24.46 & 4.17 & 35.71 & 11.76 & 21.43 & 9.52 & 15.38 & 0 & 0 & 0 \\
\hline Security & 0 & 0 & 0 & 11.76 & 0 & 47.62 & 0 & 0 & 0 & 0 \\
\hline Aesthetic & 0 & 0 & 0 & 0 & 0 & 0 & 7.69 & 0 & 0 & 0 \\
\hline Transport & 0 & 12.5 & 0 & 0 & 0 & 0 & 0 & 80 & 0 & 100 \\
\hline No reason & 25.77 & 4.17 & 7.14 & 11.76 & 0 & 19.05 & 19.23 & 20 & 40 & 0 \\
\hline
\end{tabular}

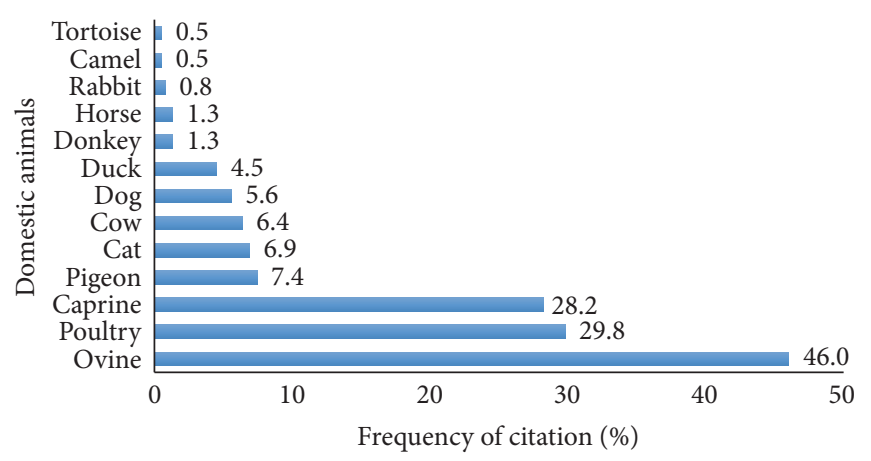

Figure 5: Domesticated animals by urban populations.

provided by the habitats, dumpsites, and vegetation. Insects are influenced by the presence of dumpsites, humans, and feed while birds like feed, vegetation, and water. As for amphibians, they are strictly related to water (Table 2).

3.5. Human Activities Affecting Biodiversity in the Cities. Three principal activities have been recognized as major threats to biodiversity of these cities. They are wastes/ dumpsites (81\%), tree logging (78\%), and urbanization (44\%) (Figure 9).

\section{Discussion}

The results of this survey in urban areas of Niger show once again the importance given by the population to biodiversity on one hand and the role it plays on the other hand. Indeed, urban ecosystems are heterogeneous, characterized by a multitude of habitats, and they consequently have significant biodiversity $[5,6,8,35,36]$. This biodiversity plays a role in urban ecosystems [2]. It is an integral part that contributes to maintaining the ecosystem balance and improving the living environment [37, 38]. In fact, it is undeniable that, aside from its environmental values, biodiversity contributes to social welfare $[39,40]$. Perceptions about values/importance of biodiversity in these two cities could influence the attitudes towards their conservation. Noneconomic values such as aesthetic values can help improve local acceptance of a particular species [41].

However, this importance is mostly attributed to domesticated biodiversity, as most of the respondents (55\%) are unaware of the presence of wildlife in urban areas. Certainly, biodiversity has always existed in urban areas but was only "unconsciously" perceived by the population [42]. Environmental education programmes can improve knowledge and attitudes change towards some animal species according to [43]. An intriguing possibility is therefore that provision of information, beyond sheer exposure to biodiversity, could help increase people's awareness about biodiversity and reconnect them to nature [44].

Among the wildlife, birds and mammals had the highest records in this study as confirmed by Luniak [9] in urban environments. It is probably because they are more visible than the others are. Dove, cockroaches, rats, and lizards are very common animals found in these cities as shown by the number of citations. Lizards often take advantage of the opportunities offered by human settlements and activities, with their large numbers of insects [45]. Cockroaches and rats are mostly attracted by dumpsites, wastewater, and unmanaged vegetation. According to Gbogbo et al. [45], small mammals such as rodents are known to thrive under 

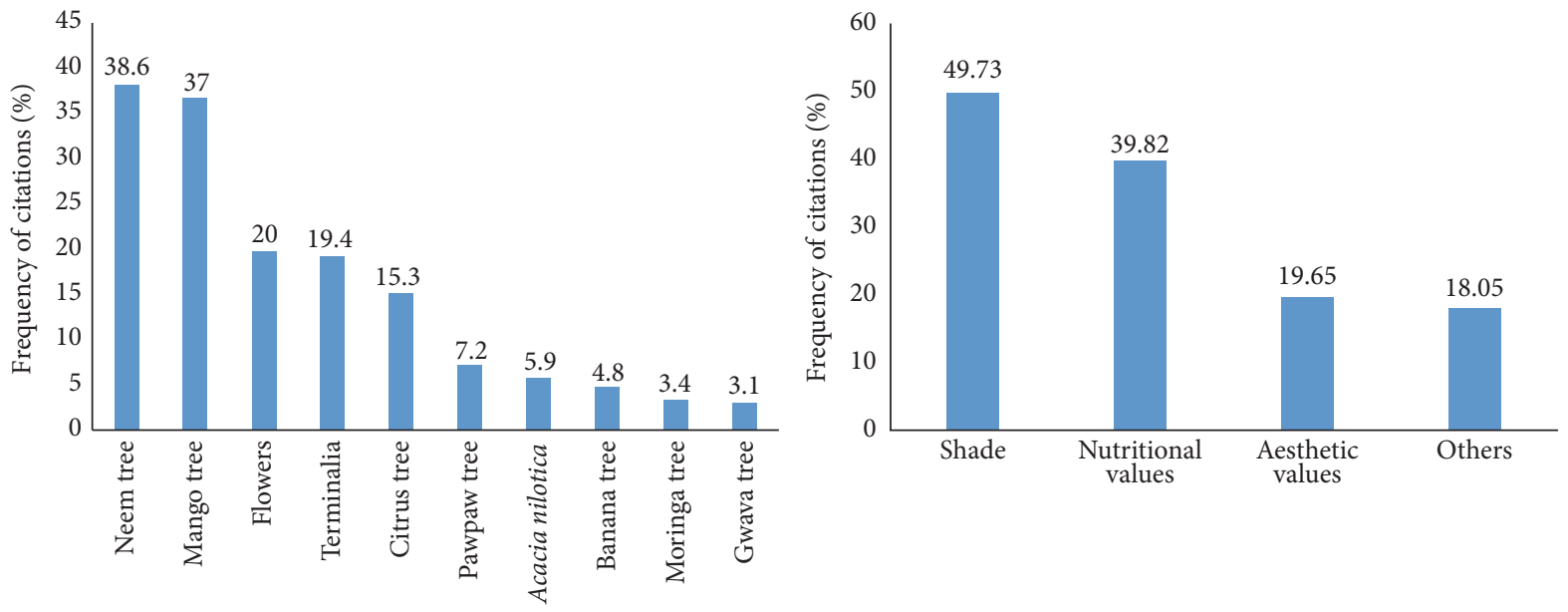

FIGURE 6: The most preferred plants and reasons.

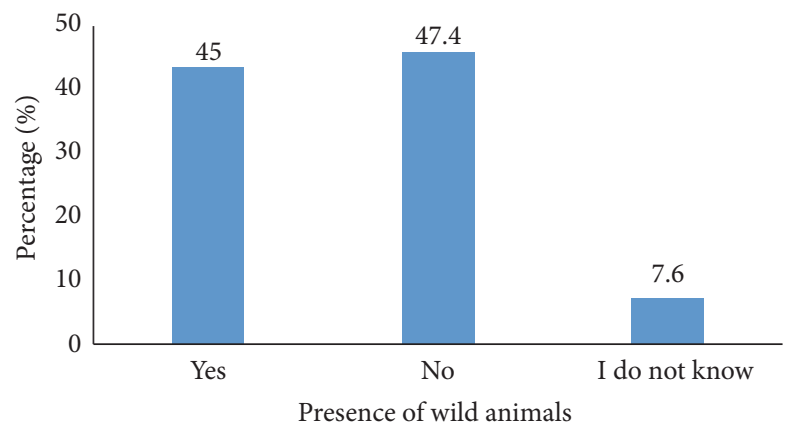

FIGURE 7: Knowledge about the presence of animal wildlife in cities.

insanitary conditions related to bad refuse disposal practices, high population growth rates, overcrowding, and poverty, among others, in urban areas. They can be used as bioindicators of environmental health or quality. The results of this survey corroborate with those of Garba et al. [26] which have shown the proliferation of rodents such as Mastomys natalensis, Rattus rattus, and Mus musculus in some districts in Niamey city. They found that these rodents could induce damage to food and food stocks, to houses, to furniture, and to clothes as mentioned by the population. These rodents could also be a cause of important health issues.

In order to reduce the abundance of rats and to prevent this damage, the population of Niamey and Maradi use cats. The use of cats for a prey-predator interaction shows the importance of animals in households and reasons that could induce the choice of animals. Populations in Niamey and Maradi cities report other reasons for the choice of both domesticated animals and plants. Animals such as sheep and goat are often selected for sociocultural reasons. They are used for feast during ceremonies such as naming and marriage but also tabaski (Eid Al Fitr) as the majority of the population is Muslim. The cities of Niamey and Maradi still have some rural characters as some people use donkeys and cows for transportation of their goods.

Preference for plants in urban areas might first be explained by the geographical location of the study area.
Indeed, Niger is a Sahelian country characterized by a dry tropical climate with very high temperatures [30], hence the need to plant trees in order to improve urban climate. The choice of shady plants covering about $50 \%$ of the responses in both cities testifies it. Plant species often used by the populations are introduced species, and the neem (Azadirachta indica A. Juss.), mango tree (Mangifera indica L.), and citrus are most preferred. These results corroborate those of Hammamatou [25] stating that neem is present in $100 \%$ of the sites studied in the city of Niamey and remains the most abundant and the most dominant plant species. Indeed, neem was introduced in Niger in 1963 and continued to be used not only in greening operations such as "green Sahel" and "green belt" but also in concessions. According to Nwokeabia [46], neem represents $90 \%$ of plant species used in revegetation programs that aimed to combat desertification in the Sahel [47]. As for fruit trees such as mango and certain citrus fruits, they were introduced during colonization in the cities of Niger.

Other factors that may influence the choice of the citizens are the constraints related to urban animal husbandry including feeding difficulties and social and health problems [48]. Animal husbandry practiced by the population in Niamey and Maradi consists of the breeding of small ruminants and birds (poultry), which represent the most domesticated animal classes in Niger. Feeding these animals, especially 

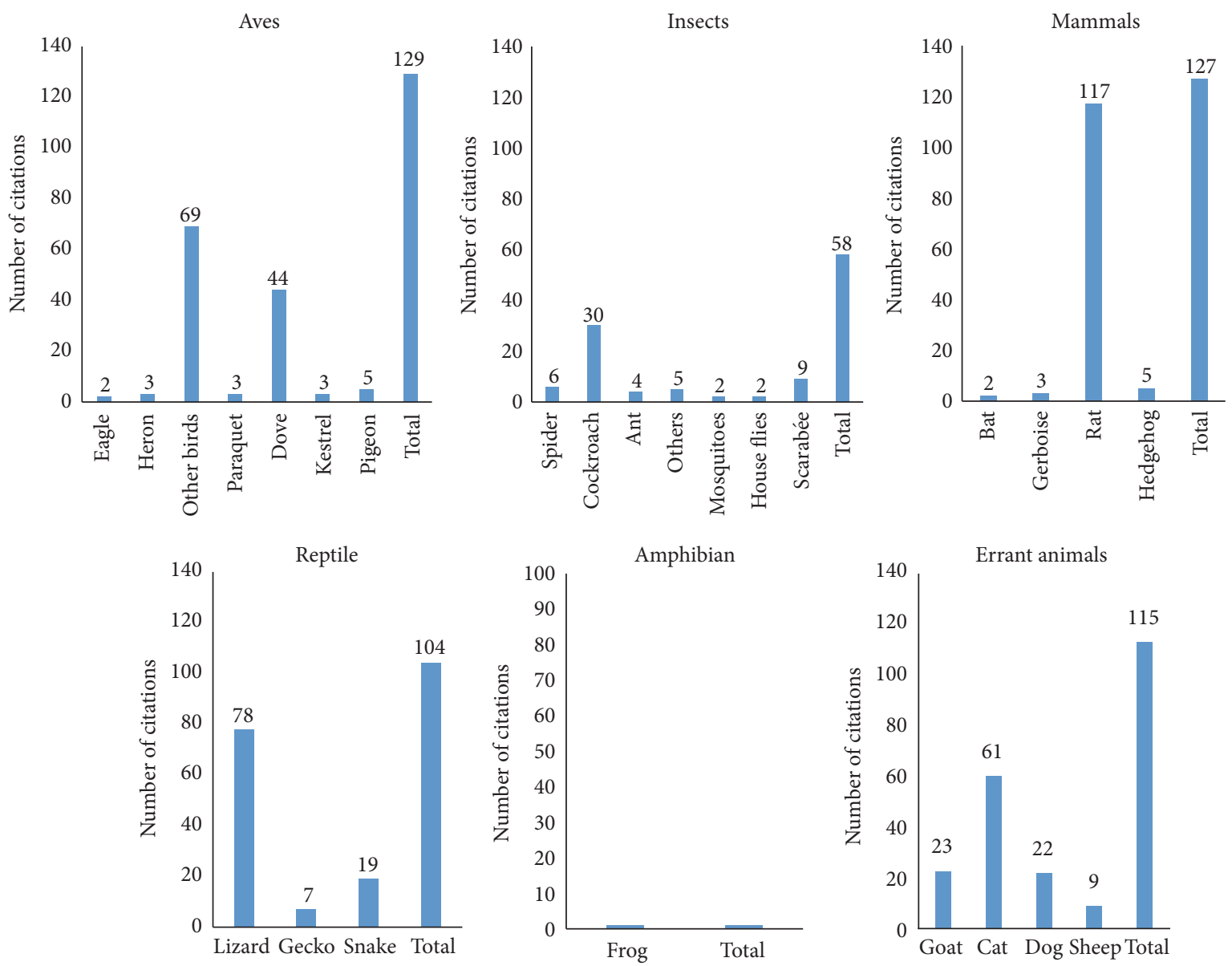

FIGURE 8: The most abundant wildlife species found in the cities.

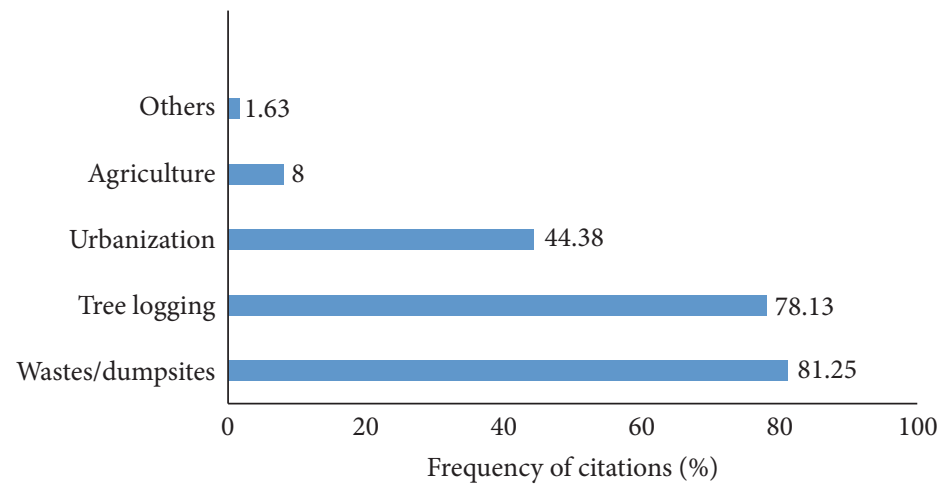

FIGURE 9: Human activities affecting the biodiversity of the cities.

small ruminants, is difficult and expensive in urban areas. Moreover, herb is difficult to get during the dry season, which lies during eight (8) to nine (9) months in these cities. These animals either are left wandering in the quarters or stall without compliance with hygiene standards in the houses. The wandering of these animals contributes to the destruction of green spaces and trees and disruption of road safety [49]. The fact that very few Nigeriens vaccinate their pets/domestic animals and meet hygiene standards contributes to the exposure of population to zoonosis in these urban areas. Even though animal husbandry is less appreciated as compared to plants in urban areas, about $47 \%$ of the respondents practice it in order to ensure financial security, socioreligious events, and subsistence. Caprine species are mostly reared in Maradi. This city is known for its caprine species called "Chévre Rousse (Capra hircus)" of Maradi, which is appreciated for its endurance and prolificacy but above all its milk and skin [49]. 
TABLE 2: Factors attracting wildlife in cities (percentage).

\begin{tabular}{|c|c|c|c|c|c|c|c|c|}
\hline \multirow{2}{*}{ Animal } & \multicolumn{8}{|c|}{ Factor } \\
\hline & Dump & Feed & Vegetation & Humans' presence & light & Water & Quiet places & No idea \\
\hline Aves & 1.55 & 45.74 & 36.43 & 0.78 & 0.00 & 7.75 & 1.55 & 6.20 \\
\hline Insects & 39.66 & 15.52 & 10.34 & 29.31 & 5.17 & 0.00 & 0.00 & 0.00 \\
\hline Mammals & 31.50 & 44.09 & 16.54 & 7.87 & 0.00 & 0.00 & 0.00 & 0.00 \\
\hline Reptiles & 25.00 & 30.77 & 26.92 & 17.31 & 0.00 & 0.00 & 0.00 & 0.00 \\
\hline Amphibians & 0.00 & 0.00 & 0.00 & 0.00 & 0.00 & 100.00 & 0.00 & 0.00 \\
\hline Errant & 23.48 & 67.83 & 4.35 & 3.48 & 0.00 & 0.00 & 0.87 & 0.00 \\
\hline
\end{tabular}

In the cities of Niamey and Maradi, the urban environment suffers from mismanagement of waste and dumpsites. People dump their waste in inadequate places even when dumpsites exist on one hand, and the municipalities do not evacuate the wastes when dumpsites are full on the other hand. These situations contribute to the proliferation of waste in the cities.

\section{Conclusion}

Local perceptions play an important role in the urban management. It should be the baseline for any environmental study or urban planning especially when dealing with cities. It helps identify the species that are preferred by the population for a better implication in the management but also identify practices that can hinder the conservation of biodiversity and the well-being of the population in urban areas. Azadirachta indica A. Juss and Mangifera indica L. are the used plants and the population often rears poultry and small ruminants. Nutritional values, climatic conditions, easy management, and even culture among others often influence the choice of these species. Cockroaches and rats mentioned by the respondents could be an indication of insanitary conditions. There is a need for environmental sensitization in order to improve the awareness of urban wildlife, animal husbandry, and also waste management in the two cities especially in the face of a burgeoning population.

\section{Appendix}

\section{Questionnaire}

The present ethnobiological survey is part of a research on urban biodiversity: perception, preference, general awareness and threats in two cities (Niamey and Maradi) of Niger.

No. questionnaire ...

Date...

\section{(I) General Informations}

(i) Gender:
(a) Female $\square$
(b) Male $\square$

(ii) Age:
(a) $<15 \square$
(b) $16-30 \square$
(c) 31-45 $\square$
(d) $>45 \square$

(iii) Religion:
(a) Islam $\square$
(b) Christianity $\square$
(c) Other $\square$

(iv) Ethnic groups:
(a) Haousa $\square$
(b) Djerma/Sonrä̈ $\square$
(c) Kanouri $\square$
(d) Touareg $\square$
(e) Fulani $\square$
(f) Arab $\square$
(g) Gourmantché $\square$
(h) Toubou $\square$
(i) Others $\square$

(v) Level of instruction:
(a) None $\square$
(b) Primary $\square$
(c) Secondary $\square$
(d) Tertiary $\square$
(e) Quranic school $\square$

(vi) Activity/Profession:
(a) Student $\square$
(b) Teacher $\square$
(c) Trader $\square$
(d) Group of fishermen, farmers, gardeners, hunters
(e) Group of health and sanitation workers $\square$
(f) Group of environmentalists $\square$
(g) Group of industries $\square$
(h) Group of urbanists $\square$ 
(i) Group of jobless people $\square$

(j) Other categories $\square$

(vii) City:
(a) Niamey $\square$
(b) Maradi $\square$

(viii) Communes:

(a) Niamey I $\square$

(b) Niamey II $\square$

(c) Niamey III $\square$

(d) Niamey IV $\square$

(e) Niamey V $\square$

(f) Maradi I $\square$

(g) Maradi II $\square$

(h) Maradi III $\square$

(II) Perceptions of the Values of Biodiversity in Urban Areas

(i) Is biodiversity important in the city?

(a) yes $\square$

(b) No $\square$

(1) If yes, what are the values of animals in a city?...

(2) If yes, what are the values of plants in a city? ...

(III) Presence and Preferences in Domesticated Biodiversity

(i) What type of biodiversity do you have in your houses?

(a) Domestic animals $\square$

(b) Plants $\square$

(c) Both $\square$

(d) None $\square$

(1) If present, what animals do you domesticate in your houses? ...

Please, explain the reasons for this selection: ...

(2) If present, what plants do you have in your houses?...

Please, explain the reasons for this selection: ...

\section{(IV) General Awareness of Wildlife in Houses or Cities}

(i) Is there any wildlife in your house or city?

(a) yes $\square$

(b) No $\square$

(c) I don't know $\square$

(1) If yes, what are they ...

(2) What have attracted them in these areas?...

(V) Threats to Biodiversity in the City (i) What human activities do have an impact on biodiversity in the city?
(a) waste/dumpsite $\square$
(b) tree logging $\square$
(c) urbanization $\square$
(d) agriculture $\square$
(e) others $\square$

\section{Competing Interests}

The authors declare that there is no conflict of interests regarding the publication of this paper.

\section{References}

[1] J. P. Collins, A. Kinzig, N. B. Grimm et al., "A new urban ecology: modelling human communities as integral parts of ecosystems poses special problems for the development and testing of ecological theory," American Scientist, vol. 88, no. 5, pp. 416-425, 2000.

[2] P. Clergeau, J. Jokimäki, and J.-P. L. Savard, "Are urban bird communities influenced by the bird diversity of adjacent landscapes?" Journal of Applied Ecology, vol. 38, no. 5, pp. 1122-1134, 2001.

[3] S. T. A. Pickett, M. L. Cadenasso, J. M. Grove et al., "Beyond urban legends: an emerging framework of urban ecology, as illustrated by the Baltimore ecosystem study," BioScience, vol. 58, no. 2, pp. 139-150, 2008.

[4] R. Jones and S. R. Leather, "Invertebrates in urban areas: a review," European Journa of Entomology, vol. 109, no. 4, pp. 463478, 2012.

[5] T. Gatesire, D. Nsabimana, A. Nyiramana, J. L. Seburanga, and M. O. Mirville, "Bird diversity and distribution in relation to urban landscape types in northern Rwanda," Scientific World Journal, vol. 2014, Article ID 157824, 12 pages, 2014.

[6] A. Muratet, P. Pellegrini, A.-B. Dufour, T. Arrif, and F. Chiron, "Perception and knowledge of plant diversity among urban park users," Landscape and Urban Planning, vol. 137, pp. 95-106, 2015.

[7] C. Purro and G. Kozlowski, Flore de la ville de Fribourg, Editions universitaires Fribourg, 608 pages dans Biodiversité des milieux urbains, Gregor Kozlowski, Les villes: des hotspotsl'exemple de Fribourg. Hotspots 8, 2003.

[8] J. Bigirimana, J. Bogaert, C. De Cannière, M.-J. Bigendako, and I. Parmentier, "Domestic garden plant diversity in Bujumbura, Burundi: role of the socio-economical status of the neighborhood and alien species invasion risk," Landscape and Urban Planning, vol. 107, no. 2, pp. 118-126, 2012.

[9] M. Luniak, "Fauna of the big city: estimating species richness and abundance in Warsaw, Poland," in Urban Ecology. An International Perspective on the Interactions between Humans and Nature, J. M. Marzluff, E. Schulenberger, and W. Endlicher, Eds., pp. 349-354, Springer, New York, NY, USA, 2008.

[10] H. Akbari, "Shade trees reduce building energy use and $\mathrm{CO}_{2}$ emissions from power plants," Environmental Pollution, vol. 116, no. 1, pp. S119-S126, 2002.

[11] B. Givoni, M. Noguchi, H. Saaroni et al., "Outdoor comfort research issues," Energy and Buildings, vol. 35, no. 1, pp. 77-86, 2003. 
[12] R. W. Furness and J. J. D. Greenwood, Birds as a Monitor of Environmental Change, Chapman \& Hall, 1993.

[13] L. L. Craft and D. M. Landers, "The effect of exercise on clinical depression and depression resulting from mental illness: a meta-analysis," Journal of Sport and Exercise Psychology, vol. 20, no. 4, pp. 339-357, 1998.

[14] A. J. Daley, "Exercise therapy and mental health in clinical populations: is exercise therapy a worthwhile intervention?" Advances in Psychiatric Treatment, vol. 8, no. 4, pp. 262-270, 2002.

[15] A. Sacker and N. Cable, "Do adolescent leisure-time physical activities foster health and well-being in adulthood? Evidence from two British birth cohorts," European Journal of Public Health, vol. 16, no. 3, pp. 331-335, 2006.

[16] L. St Leger, "Health and nature-new challenges for health promotion," Health Promotion International, vol. 18, no. 3, 2003.

[17] R. S. Ulrich, "View through a window may influence recovery from surgery," Science, vol. 224, no. 4647, pp. 420-421, 1984.

[18] K. C. Seto, B. Güneralp, and L. R. Hutyra, "Global forecasts of urban expansion to 2030 and direct impacts on biodiversity and carbon pools," Proceedings of the National Academy of Sciences of the United States of America, vol. 109, no. 40, pp. 16083-16088, 2012.

[19] United Nations, World urbanization prospects: the 2007 revision, 2009.

[20] K. Tzoulas and P. James, "Making biodiversity measures accessible to non-specialists: an innovative method for rapid assessment of urban biodiversity," Urban Ecosystems, vol. 13, no. 1, pp. 113-127, 2010.

[21] A. S. Illiassou, A. Diouf, M. B. Moussa, A. S. Sadda, A. Mahamane, and M. Saadou, "Dynamics of a third world city: case of niamey," Journal of Geography and Regional Planning, vol. 8, no. 5, pp. 120-130, 2015.

[22] Institut National de la Statistique. (INS), Présentation des résultats préliminaires du quatrième (4ième) recensement général de la population et de l'habitat (RGP/H) 2012.10 pages, 2013.

[23] G. Turner-Erfort, "Public awareness and perceptions of biodiversity," Transactions of the Illinois State Academy of Science, vol. 90, no. 3-4, pp. 113-121, 1997.

[24] M. Saadou, "Evaluation de la biodiversité biologique au Niger: éléments constitutifs de la biodiversité végétale. Conseil National de l'Environnement pour un Développement Durable SE/CNEDD. Projet NER/97/G31/A/1G/99," Stratégie Nationale et plan d'action-Diversité Biologique, 138 pp, 1998.

[25] M. Hammamatou, Inventaire des Plantes Exotiques de la Ville de Niamey, Mémoire DEA, 1999.

[26] M. Garba, M. Kane, S. Gagare et al., "Local perception of rodent-associated problems in Sahelian urban areas: a survey in Niamey, Niger," Urban Ecosystems, vol. 17, no. 2, pp. 573-584, 2014.

[27] K. H. Motcho, "Community restructuring within the Niamey urban area," Revue de Geographie Alpine, vol. 92, no. 1, pp. 111124, 2004.

[28] M. Ibrahim, M. Saadou, A. Laminou, and I. M. Mahamadou, "Niger," Niger: Rapport de pays pour la conférence technique internationale de la FAO sur les ressources phytogenetiques, 1995.

[29] O. Ahmed and B. Rouscoua, "Analyse diagnostique du bassin du fleuve Niger bilan et analyse des aspects hydroenvironnementaux, écologiques et socio-économiques du bassin du Fleuve Niger au Niger," Rapport Final. FEM Project PDF6B- RAF99G41/A/1G/50, 2001.

[30] Direction Nationale de la Météorologie, République du Niger, 2014.

[31] H.-F. Hsieh and S. E. Shannon, "Three approaches to qualitative content analysis," Qualitative Health Research, vol. 15, no. 9, pp. 1277-1288, 2005.

[32] S. Cavanagh, "Content analysis: concepts, methods and applications," Nurse Researcher, vol. 4, no. 3, pp. 5-16, 1997.

[33] A. Laouali, I. Guimbo, M. Larwanou, M. Inoussa, and A. Mahamane, "Utilisation de Prosopis africana (G. et Perr.) Taub dans le sud du département d'Aguié au Niger: les différentes formes et leur importance," International Journal of Biological and Chemical Sciences, vol. 8, no. 3, pp. 1065-1074, 2014.

[34] K. R. Sambiéni, M. S. Toyi, and A. Mama, "Perception paysanne sur la fragmentation du paysage de la Forêt classée de l'Ouémé Supérieur au nord du Bénin," VertigO. La revue électronique en sciences de l'environnement, vol. 15, no. 2, 2015.

[35] M. L. McKinney, "Effects of urbanization on species richness: a review of plants and animals," Urban Ecosystems, vol. 11, no. 2, pp. 161-176, 2008.

[36] E. Shochat, S. B. Lerman, J. M. Anderies, P. S. Warren, S. H. Faeth, and C. H. Nilon, "Invasion, competition, and biodiversity loss in Urban ecosystems," BioScience, vol. 60, no. 3, pp. 199-208, 2010.

[37] S. Manusset, "Impacts psycho-sociaux des espaces verts dans les espaces urbains," Développement Durable et Territoires, vol. 3, no. 3, 2012.

[38] A. A. Osseni, M. I. Toko, B. A. C. Tohozin, and B. Sinsin, "SIG et gestion des espaces verts dans la ville de PortoNovo au Bénin," Tropicultura, vol. 33, no. 2, pp. 146-156, 2015.

[39] D. C. Dearborn and S. Kark, "Motivations for conserving urban biodiversity," Conservation Biology, vol. 24, no. 2, pp. 432-440, 2010.

[40] B. Polorigni, R. Radji, and K. Kokou, "Perceptions, tendances et préférences en foresterie urbaine: cas de la ville de Lomé au Togo," European Scientific Journal, vol. 10, no. 5, pp. 261-277, 2014.

[41] J. R. de Pinho, C. Grilo, R. B. Boone, K. A. Galvin, and J. G. Snodgrass, "Influence of aesthetic appreciation of wildlife species on attitudes towards their conservation in Kenyan agropastoralist communities," PLoS ONE, vol. 9, no. 2, Article ID e88842, 2014.

[42] N. Blanc, Des milieux de vie à l'écosystème urbain. Écologie de Politique, 2000.

[43] E. Sousa, V. Quintino, J. Palhas, A. M. Rodrigues, and J. Teixeira, "Can environmental education actions change public attitudes? an example using the pond habitat and associated biodiversity," PLoS ONE, vol. 11, no. 5, Article ID e0154440, 2016.

[44] A. Shwartz, A. Turbé, L. Simon, and R. Julliard, "Enhancing urban biodiversity and its influence on city-dwellers: an experiment," Biological Conservation, vol. 171, pp. 82-90, 2014.

[45] F. Gbogbo, D. Attuquayefio, and Krobea-Asante, Rodents and Herpetofauna (Reptiles and Amphibians) as Household Pests in the Accra Metropolis, Ghana, 2009.

[46] O. D. Nwokeabia, Annual Report. Federal Department of Forestry, Federal Ministry of Agriculture, Abuja, Nigeria, 46 pages, 1994.

[47] M. K. Sateesh, Microbiological investigations on die-back disease of neem (Azadirachta indica A. Juss.) [Ph.D. thesis], University of Mysore, Mysore, India, 1998. 
[48] L. Ali, P. Van den Brosche, and E. Thys, "Enjeux et contraintes de l'élevage urbain et périurbain des petits ruminants à Maradi au Niger: quel avenir?” Revue Elevage Médecine Vétérinaire Pays Tropicaux, vol. 56, no. 1-2, pp. 73-82, 2003.

[49] J. Pagot, "L'elevage en Pays Tropicaux," in Techniques Agricoles et Productions Tropicales, ACCT, pp. 315-442, Edition GP Maisonneuve \& Larose, Paris, France, 1985. 


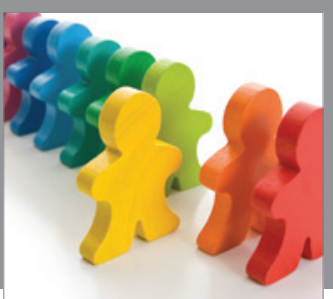

Autism

Research and Treatment
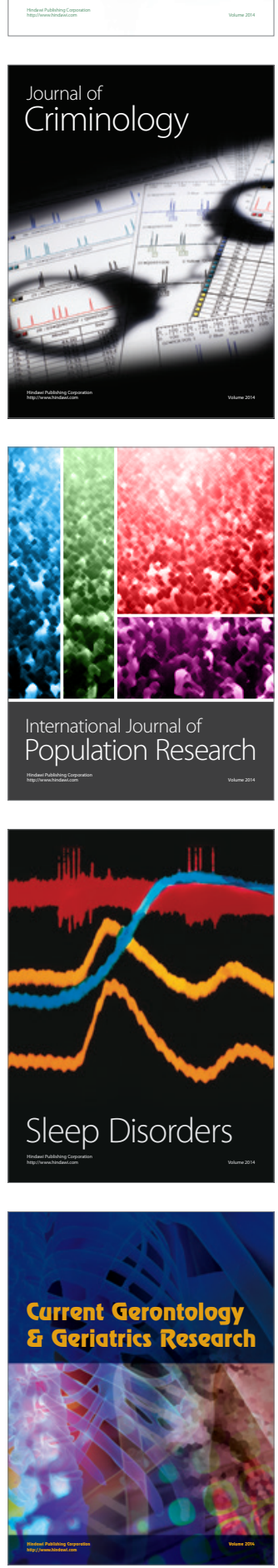

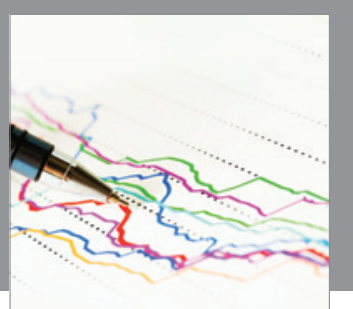

Economics

Research International
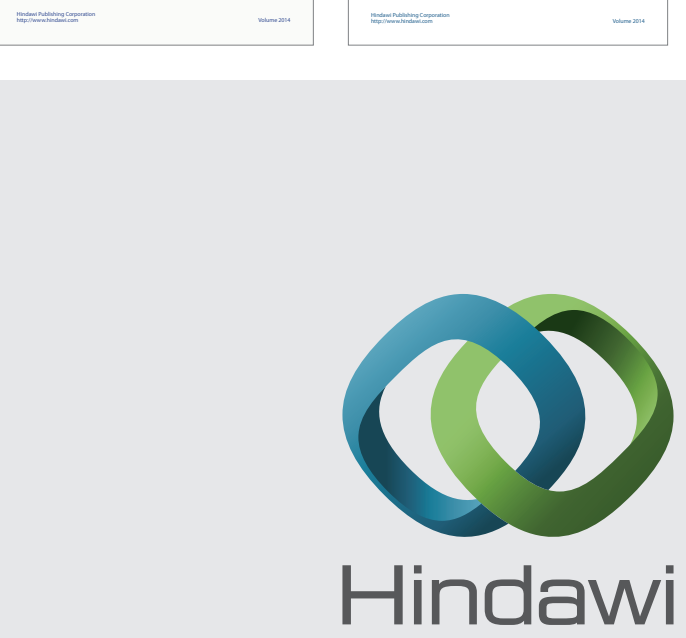

Submit your manuscripts at

http://www.hindawi.com
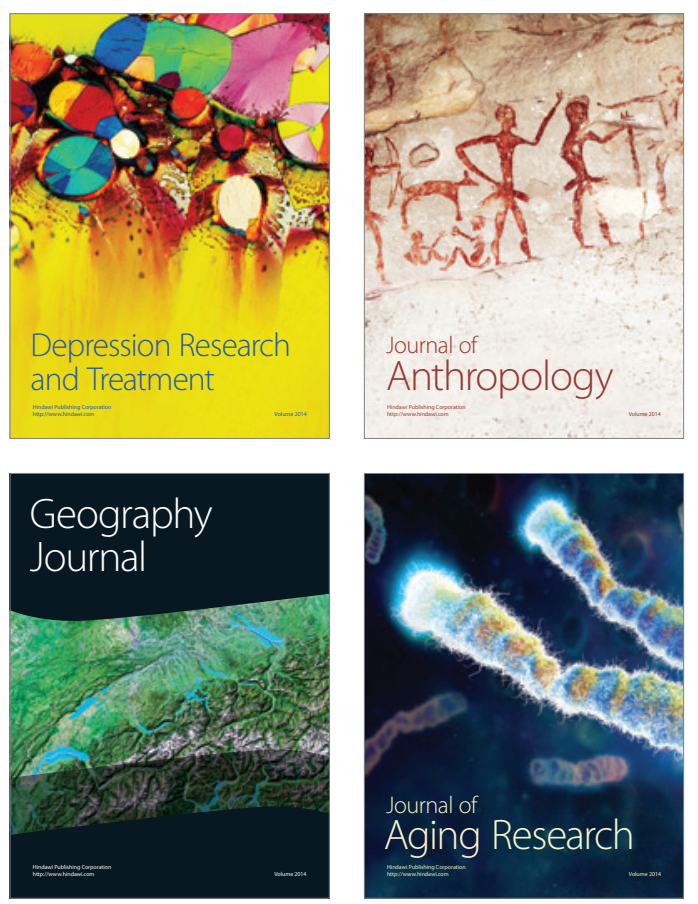
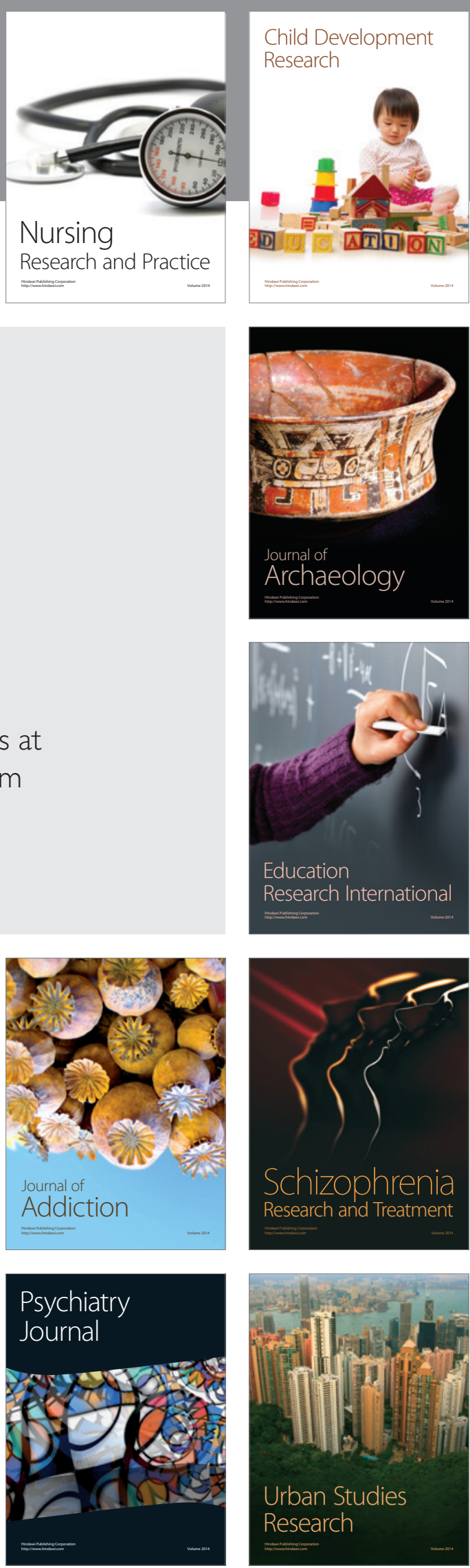